\title{
WHAT DO TURKISH ADULTS ATTRIBUTE THEIR HAPPINESS AND UNHAPPINESS TO IN DAILY LIFE?
}

\author{
Yetişkinlerin Günlük Yaşamlarında Mutluluk ve \\ Mutsuzluk Nedenleri
}

\begin{abstract}
Ali ERYILMAZ ${ }^{1}$
$\ddot{O} z$

Bu çalışma, yetişkinlerin günlük yaşamda mutluluk ve mutsuzluk nedenlerine yönelik yüklemelerini ve de günün belirli zaman dilimlerine göre onların mutluluk durumlarının değişip değişmediğini belirlemek amacıyla gerçekleştirilmiştir. Çalışmaya 28-65 yaşları arasında 31 kadın ve 37 erkek olmak üzere toplam 68 yetişkin katılmıştır. Çalışmada doğal deneyim örnekleme yöntemi kullanılmıştır. Veriler, doğal deneyim örnekleme formu ve kişisel bilgi formu aracılı̆̆ ile toplanmıştır. Çalışmada veriler, cümle bazında içerik analizi tekniği ile analiz edilmiştir. Analiz sonuçlarına göre yetişkinlerin evde, ev dışında ve iş yerinde olmak üzere mutluluk ve mutsuzluk nedenlerinin farklılaştı̆̆ bulunmuştur. Ayrıca, günün dilimlerine göre yetişkinlerin mutluluk ve mutsuzluk durumlarının da farklılaştı̆̆ bulunmuştur.
\end{abstract}

Anahtar Kelimeler: Mutluluk, mutsuzluk, yetişkin.

\section{Abstract}

The present study aims to focus on what Turkish adults attribute their happiness and unhappiness to in their daily lives, and whether the frequency of the cases of happiness and unhappiness does vary depending on certain periods of the day. 68 adults participated in this study. The method was experience sampling method. One experience sampling data form and one personal information form were used. The sentence-based content analysis method was used. The results revealed that causes of the happiness and unhappiness of Turkish adults seem to vary conditional on three physical contexts, and the ratio of happiness was much higher than that of

\footnotetext{
${ }^{1}$ Doç. Dr.; Osmangazi Üniversitesi, Eğitim Fakültesi, Eğitim Bilimleri Bölümü, Eskişehir, erali76@hotmail.com
} 
unhappiness. The frequency of the cases of happiness and unhappiness varied in accordance with the periods of the day.

Key Words: Happiness, unhappiness, adults

\section{Introduction}

There are quite a few tasks and responsibilities to be assumed by adults once they have grown out of childhood and adolescence, such as pursuing career, settling down through marriage, assuming the responsibility of parenthood, and raising children (Arnet 2001). However, living their lives with a view towards only achieving these tasks and responsibilities may bore adults and make life unbearable for them later on in life. Therefore, affections experienced by adults who are seeking to liven up their ordinary lives are of great importance. It is happiness and unhappiness that come to the fore when it comes to mentioning these affections. There are known to be several studies in the literature that have determined happiness and unhappiness to be "result" variables. Even so, the amount of research into how adults happen to experience both happiness and unhappiness in daily life is insufficient.

There are varying factors associated with the happiness experienced by adults, which can be categorized under three main categories. Of these, genetic predisposition is the first one, which accounts for $50 \%$ of the happiness observed in individuals (Lucas, 2008; Lykken \& Tellegen 1996; Weiss, Bates \& Luciano 2008). The most prominent of the genetic factors are extroversion and neuroticism, both of which are personality traits (Brebner, 1998; Furnham \& Cheng, 1997; Penley \& Tomaka, 2002). Secondly, there are some psychological factors associated with happiness in adults, such as self-esteem, 
perceived control, optimism, satisfaction of needs, and striving for goals, (Deci, Connell \& Ryan, 1989; Lyubomirsky, 2001; Mauss et al., 2011; Myers \& Diener, 1995; Sheldon \& Elliot, 1999; Sheldon, Ryan \& Reis, 1996; Steel, Schmidt \& Shultz, 2008). Finally, there are some contextual and demographic factors affecting happiness of adults, such as supportive social environments, satisfaction of desires through various activities, making money, gender, marriage, health condition, and establishing good relationships with neighbours (Argyle, 1999; Fowler \& Christakis, 2008, Myers \& Diener, 1995).

Most of the studies into unhappiness carried out so far have focused predominantly upon such psychological disorders as anxiety and mood disorders (Myers, 2000). In addition to these, there are known to be scientific studies conducted on both very happy and very unhappy people, an example of which is that by Diener and Seligman (2002). According to this study, unhappy people tend to have fewer friends, develop poor familial relationships, and fail to build up positive relationships with their romantic partners. Furthermore, these individuals have been reported to suffer more from loneliness, apart from being inclined to less extroverted and more neurotic. Other studies have also demonstrated that unhappy individuals tend to evaluate themselves and that which happens around them more negatively than the happy ones (Lyubomirsky, 2001; Lyubomirsky \& Ross, 1999; Lyubomirsky \& Tucker, 1998). Likewise, having marital problems, domestic conflicts, and negative events affecting individuals have been considered to some of the causes of unhappiness (Fu \& Parahoo, 2008).

A good analysis of the abovementioned studies reveals that they are mainly concerned with the causes of long-term happiness and 
unhappiness. However, they have neglected to look into the perception of adults on the causes of happiness and unhappiness in daily life. In other words, these studies have looked into the causes of happiness and unhappiness in terms of the "result" variables. Nonetheless, a need also arises for determining the causes of momentary happiness or unhappiness that individuals experience in daily life. Thus, the present study aims to investigate the causes of happiness and unhappiness of adults in their daily lives. As a result, answers to the questions below were sought in the present study.

1) What are the causes of happiness of adults in their daily lives, be it inside or outside home or at work?

2) What are the causes of unhappiness of adults in their daily lives, be it inside or outside home or at work?

3) What are the causes of being neutral in terms of happiness of adults in their daily lives, be it inside or outside home or at work?

4) Does the frequency of the cases of happiness and unhappiness vary in accordance with the periods of the day (e.g. morning, afternoon, evening)?

\section{Method}

\section{Research Design and Procedure}

The present study aims to focus on the causes of happiness adopted by adults in in daily life, and whether the frequency of the cases of happiness and unhappiness varies depending on the certain periods of the day. The distinguishing feature of this study is that it focuses mainly on the experience sampling method. The states of happiness of the same participants were measured qualitatively for ten times, hence the design of this study appears to be of a longitudinal one. 
The data for this study were obtained during the 2012-013 educational semester from the family members of 68 students studying at Eskişehir Osmangazi University, Turkey. Since they were easily accessible and data collection was much more convenient, the family members of these students were chosen as samples for the present study. As to the criteria determined for choosing eligible participants, care was taken to include those with a middle SES, those perceiving themselves as adults, those lacking a chronic disease, and those being between 28 and 65 years. The data for the present study were acquired by means of a one-to-one interview over the phone from October 2012 through January 2013. All the adults taking part in the study were called for ten times during the study period, 3 of these calls made in the morning, 3 in the afternoon and 4 in the evening time. By the way, all the phone calls were made between 8 a.m. and 11 p.m.

The present study undertook the sentence-based content analysis in order to analyse the data. The author cooperated with one specialist in educational psychology and one in clinical psychology while achieving the content analysis. Before the analysis process was launched, a sentence evaluation form had been prepared. This was designed in such a way as to identify and place all the sentences derived from the data sets under the proper category (e.g. very appropriate, appropriate, and not appropriate). All the sentences that were found "very appropriate" and "appropriate" were placed under the relevant category.

However, the experts gathered once more to decide on which categories the sentences that were found "not appropriate" could be put in, as a result of which these sentences were unanimously placed in the proper category. Some of the participants came up with more than one 
responses to the questions they were directed. Therefore, analyses were achieved on a sentence basis, rather than on an individual basis, which is why the number of sentences outnumber the individuals. Furthermore, in the course of categorization, theoretical and empirical studies into happiness were taken advantage of (Argyle, 1999; Diener \& Seligman, 2002; Lyubomirsky, 2001; Myers, 2000; Myers \& Diener, 1995; Sheldon, Ryan \& Reis, 1996; Takach \& Lyubomirsky, 2006). In order to determine whether the frequency of the cases of happiness and unhappiness varies depending on the certain periods of the day, the chisquare $\left(\mathrm{X}^{2}\right)$ test of independency and goodness of fit test was used.

\section{Participants}

The data for this study were obtained during the 2012-013 educational semester from the family members of students studying at Eskişehir Osmangazi University, Turkey. At the beginning of the present study, 82 adults volunteered to participate in the present study, and even so, upon demographic and descriptive analyses, 14 individuals were excluded from the study, since they did not meet the criteria of the inclusion. As a result, the remaining 68 adults were assigned to be suitable for the study. At the beginning of the study, the participants were also informed about the purposes of the present study, on the principle of voluntariness and ethical rules being considered. The adults also have such job as housewives, civil servants, workers, selfemployed businesswomen. Additional demographic characteristics of the participants in this present study are summarized in Table 1. 
Table 1. Descriptive statistics for demographic characteristics of the participants

\begin{tabular}{llll}
\hline & Variables & $\mathrm{f}$ & $\%$ \\
\hline Gender & Female & 31 & 45.6 \\
\cline { 2 - 4 } & Male & 37 & 54.4 \\
\hline Education & <High school & 24 & 35.29 \\
& High school graduate & 18 & 26.47 \\
& Baccalaureate & 26 & 38.24 \\
\hline Marital status & Married/living as & 57 & 83.9 \\
& Single & 8 & 11.6 \\
& Widowed & 1 & 1.5 \\
& Divorced & 2 & 2.9 \\
\hline
\end{tabular}

\section{Instruments}

Personal information form: In order to define demographic features of the adults the personal information form was designed. There was such information as the age, gender, occupation, education, chronic diseases, marital status and so forth in the personal information form. Beside, to determine the SES of the participants, one important question was asked the participants: "Which socioeconomic status (low, middle, high) do you identify yourself with?"

Experience sampling data form: So as to determine the status and causes of the happiness of the participants, an experience sampling data form was used. Such open-ended questions as "Where are you? What time is it now? Are you happy? Why are you (not) happy?" were included in this form. There were also such information as age, time, name, and gender of the participants in this form. 


\section{Findings}

\section{Descriptive statistics}

Table 2. Descriptive statistics regarding the happiness status of adults

\begin{tabular}{lcc}
\hline Domains of happiness & $\mathrm{f}$ & $\%$ \\
\hline Happiness at home & 243 & 35.73 \\
Happiness outside home & 153 & 22.5 \\
Happiness at work & 85 & 12.5 \\
Being neutral & 39 & 5.74 \\
Unhappiness at home & 73 & 10.74 \\
Unhappiness outside home & 46 & 6.76 \\
Unhappiness at work & 41 & 6.03 \\
\hline Total & 680 & 100 \\
\hline
\end{tabular}

Descriptive statistics of the happiness status of the adult participants have been provided for the present study. The findings reveal that adults were happy by $70.73 \%$, and the ratio of unhappiness was $23.53 \%$. As for being neutral in terms of happiness and unhappiness, it was $5.74 \%$.

\section{Findings about the causes of happiness and unhappiness}

Table 3. Causes of happiness

\begin{tabular}{llcc}
\hline $\begin{array}{l}\text { Context of } \\
\text { happiness }\end{array}$ & Categories of the causes of happiness & $\begin{array}{c}\mathrm{f} \\
\text { (sentences })\end{array}$ & $\begin{array}{c}\% \\
\text { (sentences) }\end{array}$ \\
\hline \multirow{5}{*}{ At home } & Having no problems in daily life & 75 & 28.84 \\
& $\begin{array}{l}\text { Building positive relationships with the } \\
\text { environment }\end{array}$ & 51 & 19.61 \\
& $\begin{array}{l}\text { Increasing their physical well-being } \\
\end{array}$ & 28 & 10.76 \\
& Satisfaction of desires & 23 & 8.84 \\
& Serforming religious duties & 22 & 8.45 \\
& $\begin{array}{l}\text { Having positive expectations relating } \\
\text { to future }\end{array}$ & 21 & 8.45 \\
& $\begin{array}{l}\text { Doing favours } \\
\text { Disappearance of monotony in life }\end{array}$ & 6 & 8.01 \\
& & 6 & 2.30
\end{tabular}




\begin{tabular}{|c|c|c|c|}
\hline & $\begin{array}{l}\text { No particular reasons for their } \\
\text { happiness }\end{array}$ & 6 & 2.30 \\
\hline & Total & 260 & 100 \\
\hline \multirow{11}{*}{$\begin{array}{l}\text { Outside } \\
\text { home }\end{array}$} & $\begin{array}{l}\text { Building positive relationships with the } \\
\text { environment }\end{array}$ & 59 & 36.41 \\
\hline & Having no problems in daily life & 25 & 15.43 \\
\hline & Satisfaction of desires & 18 & 11.11 \\
\hline & $\begin{array}{l}\text { Having positive expectations relating } \\
\text { to future }\end{array}$ & 15 & 9.25 \\
\hline & Performing religious duties & 13 & 8.02 \\
\hline & Satisfaction of the need for competence & 11 & 7.79 \\
\hline & Doing favours & 8 & 4.93 \\
\hline & Feeling gratitude & 6 & 3.70 \\
\hline & Favourable weather conditions & 4 & 2.46 \\
\hline & Receiving good news & 3 & 1.85 \\
\hline & Total & 162 & 100 \\
\hline \multirow{9}{*}{ At work } & Having no problems in daily life & 32 & 34.78 \\
\hline & Preoccupation with a job & 20 & 21.73 \\
\hline & $\begin{array}{l}\text { Experiencing positive life experiences } \\
\text { outside the workplace }\end{array}$ & 13 & 14.13 \\
\hline & Increasing their physical well-being & 10 & 10.86 \\
\hline & End of the business day & 9 & 9.78 \\
\hline & Satisfaction of desires & 5 & 5.43 \\
\hline & $\begin{array}{l}\text { No particular reasons for their } \\
\text { happiness }\end{array}$ & 2 & 2.17 \\
\hline & Getting a promotion at work & 1 & 1.08 \\
\hline & Total & 92 & 100 \\
\hline
\end{tabular}

Results of the analyses revealed that causes of the happiness experienced by adults could be assessed in consideration of three significant physical contexts: at home, outside home and at work. It is interesting to note that the causes of the happiness experienced relating to these contexts draw attention to two common aspects: having no problems in daily life (e.g. Everything is going fine, There is nothing for 
me to be bothered about, There is no problem), and satisfaction of desires (e.g. I have just eaten my favourite food, I'm going for a stroll, I'm watching my favourite soap opera).

Likewise, the causes of the happiness experienced relating to inside and outside home point to 5 common aspects: building positive relationships with the environment (e.g. Being visited by others cheers me up, I'm happy because I can converse with the people I love most, Spending time with my friends makes me happy), having positive expectations relating to future (e.g. I'm in expectation of some good news about my job, I'll be visiting my darling and family next week, I'll be going abroad to continue my studies soon), performing my religious duties (e.g. I'm happy that I can perform my prayers, I'm happy to be able to pray to God, Praying helps me take my mind off my personal problems), satisfaction of the need for competence (e.g. I'm happy that I can read more books on archaeology, which will help me purse career in this field, I'm a diving teacher and have just accomplished a great diving, I'm happy because I'm furnishing myself with good knowledge that will benefit my children), doing favours (e.g. I'm happy to have been able to afford the bed my son asked me for, I'm happy to be able to help my parents on the farm in the village, I'm happy that I was able to lend $a$ hand to someone in dire need of my help).

Adults tend to be happy both at home and at work by increasing their physical well-being (e.g. I have been lucky enough to take a deep rest today, so I'm feeling great, Break times at work help me feel invigorated afterwards, I'm happy that I was able to rest). However, the participants of the present study cited no particular reasons for their happiness either at home or at work. Some of them cited the 
disappearance of monotony in life as a cause of happiness when they were home (e.g. I'm happy that it is raining now after such a long time, It is my daughter's birthday, which makes me happy, I'm happy to have finally bought a new house). As to the causes of happiness outside home, they presented different causes, such as favourable weather conditions (e.g. It is a very nice day with lots of sunlight, There is a lot of fresh air to breathe today, It is shining brightly today, which is so refreshing) feeling gratitude (I'm happy to be able to support my family through a fixed job, I'm happy because I'm no longer of out of work, I have got enough means to afford all my needs), receiving good news (e.g. I'm happy to have learned the sex of my new baby, I'm happy that I have just got a job that will provide me with the amount of salary I have always longer for, I'm happy because I've just received some good but unexpected news from someone). As for the causes of happiness at work, they came up with very interesting causes, such as preoccupation with a job (e.g. I'm happy because I'm busy working, I'm happy not to be idle anymore, I'm happy to be in charge of my own business) going through positive life experiences outside the workplace (e.g. I'm happy because I walked all the way to work with my wife after having a nice breakfast together, I'm happy because my mother has just recovered from her illness, I'm happy because an intimate friend of mine was able to handle a problem with the farm on my behalf), end of the business day (e.g. I'm happy because I'm finally off home from work, I'm happy because I will be going home soon now that I'm finished with work for today, I'm happy because I have nothing left for tomorrow relating to work) getting a promotion at work (e.g. I'm happy because I have been appointed manager at work). 
Table 4. Causes of unhappiness

\begin{tabular}{|c|c|c|c|}
\hline $\begin{array}{l}\text { Context of } \\
\text { unhappiness }\end{array}$ & $\begin{array}{l}\text { Categories of the causes of } \\
\text { unhappiness }\end{array}$ & $\begin{array}{c}\mathrm{f} \\
\text { (sentenc } \\
\text { es ) }\end{array}$ & $\begin{array}{c}\% \\
\text { (sentence } \\
\text { s ) }\end{array}$ \\
\hline \multirow{6}{*}{ At home } & $\begin{array}{l}\text { Going through a negative } \\
\text { experience }\end{array}$ & 25 & 34.72 \\
\hline & Being physiologically unwell & 21 & 29.16 \\
\hline & $\begin{array}{l}\text { Having problematic relationships } \\
\text { at home }\end{array}$ & 17 & 23.61 \\
\hline & Monotonous way of life & 5 & 6.94 \\
\hline & $\begin{array}{l}\text { Failure to satisfy the need for } \\
\text { autonomy }\end{array}$ & 4 & 5.55 \\
\hline & Total & 72 & 100 \\
\hline \multirow{6}{*}{ Outside home } & $\begin{array}{l}\text { Going through a negative } \\
\text { experience }\end{array}$ & 16 & 39.02 \\
\hline & Being physiologically unwell & 15 & 36.58 \\
\hline & $\begin{array}{l}\text { Failure to satisfy the need for } \\
\text { autonomy }\end{array}$ & 5 & 12.19 \\
\hline & Suffering anxiety outside home & 4 & 9.75 \\
\hline & Monotonous way of life & 1 & 2.44 \\
\hline & Total & 41 & 100 \\
\hline \multirow{5}{*}{ At work } & $\begin{array}{l}\text { Going through a negative } \\
\text { experience }\end{array}$ & 14 & 41.17 \\
\hline & Being physiologically unwell & 11 & 32.35 \\
\hline & Overwhelming burden of business & 6 & 17.64 \\
\hline & $\begin{array}{l}\text { Failure to satisfy the need for } \\
\text { autonomy }\end{array}$ & 3 & 8.82 \\
\hline & Total & 34 & 100 \\
\hline
\end{tabular}

It is interesting to note that the causes of unhappiness experienced by adults relating to being home, being outside home and being at work seem to have three common points, such as going through a negative experience (e.g. I'm unhappy because I burned the food and all the ingredients were wasted, I'm unhappy because I have just brought the car to the garage for repair, which is very costly, I'm unhappy because I have had a row with a colleague of mine), being 
physiologically unwell (e.g. I'm unhappy because I've gone down with the flu and so feel so lethargic, I'm unhappy because I couldn't sleep well last night, and so am sleepy, I'm unhappy because I couldn't take a rest as a teacher during the break-time, which is always so short), failure to satisfy the need for autonomy (e.g. I'm unhappy because I have to dash home to cook for my family during lunch break, which leaves me with little time to rest, I'm unhappy because I have to slave at work as a civil servant, I'm unhappy because I have to work overtime for free even at the weekend, when I normally don't have to work).

When it comes to the common points as regards the causes of unhappiness in adults both inside and outside home, it was determined that the participants viewed leading a monotonous way of life as a distinct cause of unhappiness (e.g. I'm unhappy because I keep doing the same thing day after day, I'm unhappy because I want to visit the village out of boredom, I'm unhappy because I have been doing the same things for ages).

In addition, there are domain-specific causes of unhappiness, such as having problematic relationships at home (e.g. I'm unhappy because my grandmother is talking too much, which annoys me, I'm unhappy because I have just had a row with my spouse, I'm unhappy because a friend of my brother's popped in very early in the morning), suffering anxiety outside home (e.g. I'm unhappy because my mother has to undergo a risky operation for her bladder, I'm unhappy because I cannot cope with the anxiety about the interview I'll be having soon), an overwhelming burden of business at workplace (e.g. I'm unhappy because there is too much I have to do at work, I'm unhappy because I'm having difficulty making the deadline of the orders placed by the 
customers, I'm unhappy because there is a lot to do when I'm so short of time).

Table 5. Causes of being neuter

\begin{tabular}{lcc}
\hline Categories of the causes of being neuter & $\begin{array}{c}\mathrm{f} \\
\text { (sentences ) }\end{array}$ & $\begin{array}{c}\% \\
\text { (sentences ) }\end{array}$ \\
\hline No valid causes for either happiness or unhappiness & 14 & 56 \\
Having both a positive and negative occasions at the & 10 & 40 \\
same time & 1 & 4 \\
Being aphetic & 25 & 100 \\
Total & & \\
\hline
\end{tabular}

As far as the causes of being neutral in terms of happiness of adults in their daily lives, be it inside or outside home or at work, the participants reported that they had no valid causes of either happiness or unhappiness (e.g. I'm neuter because I find no good reasons for happiness or unhappiness, I'm neuter because I still haven't experienced an event that would bring me either happiness or unhappiness, I'm neuter because nothing is different today) having both a positive and negative occasions at the same time (e.g. I'm neuter because I'm in the summer resort, which is good, but will be moving back to the city soon now that summer is over, which is bad, I'm neuter because I'm happy to be with my family but also unhappy due to feeling fatigued, I'm neuter because even though I did some shopping for my daughters with pleasure, I had to spend a good deal of money for that) being aphetic (e.g. I'm neuter because I'm too tired to feel anything, either positive and negative).

Findings of the cases of happiness and unhappiness according to the certain periods of the day. 
The present study sought to determine if happiness and unhappiness of the participants varied according certain periods of the day as a whole, as well as seeking to determine if their happiness and unhappiness varied independently. However, no statistical analysis concerning neutrality in terms of happiness and unhappiness could be made due to the insufficient number of adults in the case of being neutral. When viewed as a whole through the chi-square $\left(\mathrm{X}^{2}\right)$ test of independency, there was no statistically significant difference $\left(\mathrm{X}^{2}=2.957 ; \mathrm{p}>0.05\right)$ between the cases of happiness and unhappiness of the adults according to certain periods of the day. Whether the cases of unhappiness of the adults varied according to certain periods of the day was analysed through the chi-square (x2) goodness-of-fit test, the results of which revealed that they varied significantly $\left(X^{2}=7.269 ; p<0.05\right)$. The period of the day in which the adults seemed to be the unhappiest was the morning time $(\mathrm{f}=67)$, the afternoon $(\mathrm{f}=48)$ and the evening time ( $\mathrm{f}=45$, respectively. As to the cases of happiness, which were also shown to vary according to certain periods of the day $\left(\mathrm{X}^{2}=8.686\right.$; $\mathrm{p}<0.05)$, the adults were the happiest in the morning ( $\mathrm{f}=183)$, the evening time ( $\mathrm{f}=167)$, and the afternoon $(\mathrm{f}=131)$ respectively.

\section{Discussion}

There are known to be a large number of studies into the happiness of adults in the literature (Deci, Connell \& Ryan, 1989; Lacey, Smith \& Ubel, 2006; Lucas, 2008; Lyubomirsky, 2001; Mauss et al., 2011; Myers \& Diener, 1995). Unlike abovementioned studies, the present study aims to investigate how adults go about their happiness and unhappiness in daily life. Diener and Seligman (2002) assert that there is no single key to achieving high levels of happiness, and explain 
this through an example of how a nice piece of symphonic music comes about. Just as a piece of symphonic music requires an assortment of musical instruments to come about, so does happiness, which is what the results of the present study are consistent with.

When happiness of the adults was evaluated in view of the events experienced by them, it becomes apparent that the ratio of happiness was much higher than that of unhappiness. This finding is consistent with the notion that a common feature of mankind is searching for happiness (Diener \& Diener, 1996; McMahon, 2006). Moreover, it has been reported that $65 \%$ of humans tend to have an average level of mental health (Hefferon \& Boniwell, 2010). Interestingly enough, the fact that $70 \%$ of the time of the adults participating in the present study was spent happily during the whole time of the study. This may partly be accounted for by the fact that only those with no chronic diseases, whether physiologically or psychologically, were included in the present study.

There are known to be a certain number of studies into using strategies for increasing happiness in individuals (Buss, 2000; Ery1lmaz, 2010, 2012; Fordyce, 1977, 1983; Takach \& Lyubomirsky, 2006). Analysis of the qualitative results of the study showed that the participants cited the strategies (e.g. satisfaction of desires, performing religious duties, building positive relationships with the environment etc) they used to increase their happiness, whether consciously or unconsciously, when they were asked to state the causes of their happiness. In other words, because the happiness of the adults increased thanks to the strategies they had developed to increase their happiness; they are understood to have perceived these strategies as causes of 
happiness. On the other hand, the adults referred to some factors as causes of happiness, such as having positive future expectations, satisfaction of the need for competence, favourable weather conditions, feeling gratitude, physical well-being, and the like. In fact, these causes, which have been determined through empirical research, are associated with the happiness of individuals (Eryllmaz, 2011; Hefferon \& Boniwell, 2010; Keller et al., 2005; Myers, 2000; Diener \& Seligman, 2002). Among the causes cited for happiness in the literature is what individuals are in possession of, besides what they are asking for, in order to be happy (Larsen \& McKibban, 2008). In keeping with this fact, individuals are inclined to cognitively evaluating their level of happiness by making a social comparison (Lyubomirsky, Tucker \& Kasri, 2001). The fact that the participants came up with conscious reasons for being happy depending on the physical context (e.g. I'm happy because I have no problems whatsoever, or I'm happy because I'm healthy), seems to be indicative of self-assessment and socialcomparison.

Previous studies have revealed that individuals tend to be happier when involved in social relationships, to which friends, intimate partners and family members are thought to contribute a good deal (Argyle, 1997; Buss, 2000; Takach \& Lyubomirsky, 2006). While its results are consistent with the abovementioned literature, the present study has also shown that not only happiness but also unhappiness of individuals has a lot to do with their social relationships. Previous studies have also concluded that such daily problems as diseases, negative personal relationships, automobiles that keep breaking down, may adversely affect their happiness (Bolger, et al., 1989). What is 
more, happiness is also believed to protect individuals from certain diseases (Argyle, 1997). While the participants of the present study reported that they were not unhappy when leading a problem-free life, they began to suffer unhappiness when problems affecting their happiness arose.

Analysis of the causes of unhappiness in adults indicates such common points as experiencing negative events, being physiologically unwell, and blockage to the need for autonomy. These findings show that individuals were deprived of the opportunity to achieve selfdetermination, which is in agreement with the theory of selfdetermination (Deci \& Ryan, 1985). However, unlike the selfdetermination theory, which deals with individuals psychologically, the results of the present study point to achieving happiness physiologically (e.g. being able to rest, having a healthy body).

The participants of this study attributed their unhappiness to leading a monotonous life, their neutrality to experiencing neither a positive nor a negative event, and their happiness to no apparent reason, which leads to the conclusion that adults appear to have one common feature, that is, the need for being stimulated optimally (Berlyne, 1960). According to the optimal stimulation theory, the brain of every single individual is in need of some stimulants to be able to function properly; therefore, individuals have a tendency to get involved in activities to provide them with stimulation as they go about their daily lives (Berlyne, 1963). As a result, some individuals taking part in the present study were unhappy or stayed neuter probably because they had not been stimulated optimally. Future studies could throw further light upon 
the relationship between optimal stimulation and happiness-increasing strategies.

The work life of individuals differs from that of home and outside home life. Due to the fact that a heavy workload inevitably results in burn-out on the part of those engaged in working life, the happiness of those working intensively is assumed to be adversely affected after some time (Schaufeli \& Baker, 2004). In line with this, the adult participants of the present study reported that they were also unhappy due to the overwhelming workload in their workplace.

Additionally, there is little information available in the literature that shows the causes attributed by individuals with a view towards considering their happiness and unhappiness in work settings. Therefore, the results of this study could provide a wide perspective on what causes of happiness and unhappiness could be or are perceived by individuals in work life. Besides, some of the adults in the present study reported to be happier when off work or when on holiday, because they are freer to spend their time however they wish. In addition, they tend to increase their happiness in the morning. These findings are consistent with those of a study by Kramer (2010).

All these taken into account, the present study has some suggestions to make. To begin with, the presence of problems seems to be related to unhappiness while the absence of them appears to be associated with happiness. Therefore, future experimental and empirical studies into happiness and unhappiness of adults could shed further light on this aspect by involving problem-solving skills. The most significant limitation of this study is that all participants were adults having no chronic illness. Similar studies should also be conducted on adults have 
chronic illness and psychiatric diagnosis. Thirdly, the data were collected through the naturalistic sampling method. Future studies could be conducted on this issue by using different samples and instruments. Finally, it can be claimed that in order to enhance the happiness of the adults, results of this study could be used in adults' daily life.

\section{References}

Argyle, M. (1997). Is happiness a cause of health? Psychology and Health, 12, 769-781.

Argyle, M. (1999). Causes and correlates of happiness. In Kahneman, D., Diener, E., and Schwarz, N. (Eds.), Well-Being: The Foundations of Hedonic Psychology (pp. 353-373). New York: Russell Sage Foundation.

Arnett, J. J. (2001). Conceptions of the transition to adulthood: Perspectives from adolescence to midlife. Journal of Adult Development, 8, 133-143.

Berlyne, D.E. (1960). Conflict, arousal, and curiosity. McGraw-Hill, New York.

Berlyne, D. E. (1963). Motivational problems raised by exploratory and epistemic behavior. In S. Koch (Eds.), Psychology: A study of a science. Vol. 5. The process areas, the person, and some applied fields: Their place in psychology and in science. New York: McGraw-Hill. Pp 284-364.

Bolger, N., DeLongis, A., Kessler, R.C., Schilling, E.A. (1989). Effects of daily stress on negative mood. Journal of personality and social psychology, 57(5), 808-818.

Brebner, J. (1998). Happiness and personality. Personality and Individual Differences. 25,279-296.

Buss, D. M. (2000). The evolution of happiness. American Psychologist, 55, 15-23.

Deci, E.L., Connell, J.P., \& Ryan, R.M. (1989). Self-determination in a work organization. Journal of Applied Psychology, 74, 580-590.

Deci, E. L., \& Ryan, R. M. (1985). Intrinsic motivation and self determination theory in human behavior. New York: Plenum Press. 
Diener, E., \& Diener, C. (1996). Most people are happy. Psychological Science, 96, 181-185.

Diener, E., \& Seligman, M.E.P. (2002). Very happy people. Psychological Science, 13, 8083.

Eryılmaz, A. (2010). Developing a scale about subjective well being increases strategies for adolescents. Journal of Turkish Psychological Counseling, 33, 81-88.

Eryılmaz, A. (2011). The relationship between adolescents' subjective well being and positive expectations towards future. Düsünen Adam The Journal of Psychiatry and Neurological Sciences, 24 (3), 209-215.

Ery1lmaz, A. (2012). A model of subjective well-being for adolescents in high school. Journal of Happines Studies, 13(2), 275-289.

Fordyce, M. W. (1977). Development of a program to increase happiness. Journal of Counseling Psychology, 24, 511-521.

Fordyce, M. W. (1983). A program to increase happiness: Further studies. Journal of Counseling Psychology, 30, 483-498.

Fowler J.H. and Christakis N.A. (2008). Dynamic spread of happiness in a large social network: longitudinal analysis over 20 years in the Framingham Heart Study. British Medical Journal 337, a2338, 23-27.

Fu, C.M., \& Parahoo, K. (2009). Causes of depression: Perceptions among people recovering from depression. Journal of Advenced Nursing, 65 (1), 101-109.

Furnham, A., \& Cheng, H. (1997). Personality and happiness. Psychological Reports, 80, 761-762.

Hefferon, K.,\& Boniwell, I. (2010). Positive psychology.NewYork:McGraw Hill.

Kramer, D. A. (2010). An unobtrusive behavioral model of gross national happiness. In Proceedings of the ACM Conference on Human Factors in Computing Systems, 287-290.

Keller, M.C., Barbara L. Fredrickson, Ybarra, O., Cote, S., Johnson, K., Mikels, J., Conway, A., \& Wager, T. (2005). A warm heart and a clear head. The contingent efects of weather on mood and cognition. Psychological Science, 16(9): 724\{731. 
Lacey, H.P., Smith, D.M., \& Ubel, P.A. (2006). Hope 1 die before 1 get old: Mispredicting happiness across the adult lifespan. Journal of Happiness Studies, 7, 167-182.

Lucas, R.E. (2008). Personality and subjective well-being. In Eid, M. and Larsen, R. J. (Eds.), The Science of Subjective WellBeing (pp. 171-194). New York: The Guilford Press.

Larsen, J.T., \& McKibban, A.R. (2008). Is happiness having what you want, wanting what you have, or both? Psychological Science, 19, 371-377.

Lyubommirsky, S. (2001). Why are some people happier than others: the role of cognitive and motivational processes in well-being. American Psychologist. Vol.56. No.3, 239-249.

Lyubomirsky, S., \& Ross, L. (1997). Hedonic consequences of social comparison: A contrast of happy and unhappy people. Journal of Personality and Social Psychology, 73, 1141-1157.

Lyubomirsky, S., \& Tucker, K. L. (1998). Implications of individual differences in subjective happiness for perceiving, interpreting, and thinking about life events. Motivation and Emotion, 22, 155-186.

Lyubomirsky, S., Tucker, K. L., \& Kasri, F. (2001). Responses to hedonically conflicting social comparisons: Comparing happy and unhappy people. European Journal of Social Psychology, 31, 511-535.

Lykken, D., \& Tellegen, A. (1996). Happiness is a stochastic phenomenon. Psychological Science, 7, 186-189.

Mauss, I.B., Savino, N.S., Anderson, C.L., Weisbuch, M., Tamir, M., \& Laudenslager, M.L. (2011). The pursuit of happiness can be lonely. Emotion, 12 (5), 908-920.

McMahon, D.M. (2006). Happiness: A history. New York: Atlantic Monthly Press.

Myers, D. G. (2000). The funds, friends, and faith of happy people. American Psychologist, 55, 56-67.

Myers, D. G., \& Diener, E. (1995). Who is happy? Psychological Science, 6, 10-19. 
Penley,J.A., \& Tomaka,J.(2002). Associations among the big-five, emotional responses, and coping with acute stress. Personality and Individual Differences. 32, 1215- 1228.

Schaufeli, W., \& Bakker, A. B. (2004). Job demands, job resources, and their relationship with burnout and engagement. Journal of Organizational Behavior, 25, 293-315

Sheldon, K.M., \& Elliot, A.J. (1999). Goal striving, need satisfaction, and longitudinal well-being: The self-concordance model. Journal of Personality and Social Psychology, 76, 482-497.

Sheldon, K.M., Ryan, R. and Reis, H.T. (1996). What makes for a good day? Competence and autonomy in the day and in the person. Personality and Social Psychology Bulletin, 22, 1270-1279.

Steel, P., Schmidt, J., \& Shultz, J. (2008). Refining the relationship between personality and subjective well-being. Psychological Bulletin, 134, 138-161.

Tkach, C., \& Lyubomirsky, S. (2006). How do people pursue happiness? Relating personality,happiness increasing strategies, and well-being. Journal of Happiness Studies, 7, 183-225.

Weiss, A., Bates, T.C., \& Luciano, M. (2008). Happiness is a personal(ity) thing: The genetics of personality and well-being in a representative sample. Psychological Science, 19, 205-210. 